\title{
PERFORMANCE OF SOCIAL WORKERS AT CHILDREN'S REHABILITATION INSTITUTION REQUIRES SPECIAL PROTECTION IN PAGADEN SUBANG
}

\author{
Novia Norma Yunita \\ Bandung Polytechnic of Social Welfare (Poltekesos), Ir. H. Juanda Street (Dago), No. 367, \\ Bandung, Novianormayunita97@gmail.com \\ Aep Rusmana \\ Bandung Polytechnic of Social Welfare (Poltekesos), Ir. H. Juanda Street (Dago), No. 367, \\ Bandung, aeprusmana6@gmail.com \\ Yudi Muryanto \\ Bandung Polytechnic of Social Welfare (Poltekesos), Ir. H. Djuanda Street (Dago), No.367, \\ Bandung yudimuryanto@yahoo.com
}

\begin{abstract}
This research contains an overview of the results of research on the Performance of Social Workers at Children's Social Rehabilitation Institution Requires Special Protection in Pagaden Subang. The objective of this research is to ascertain the performance social workers which include the aspects of work performance, discipline, creativity, collaboration, and responsibility. Researcher used a descriptive method with a qualitative approach. Informants in this research were determined using purposive sampling with a total of 8 informants consisting of structural officials, social workers, caregivers and foster children. Data collection technique was used indepth interviews; observation and documentation study. The research results showed that social workers at the Children's Social Rehabilitation Institution Requires Special Protection in Pagaden Subang have a good work performance, disciplined, creative, cooperation and coordinate with various parties, and of course responsible in carrying out tasks. However, social workers are not capable and serious in carrying out their duties. Based on this the researcher proposes the program "Capacity Building of Social Workers through Technical Guidance in Providing Services to Children" which aims to increase the awareness of social workers about the urgency in handling children problems, increase the motivation of social workers to improve their skills and sincerity in carrying out tasks, and develop techniques in providing services to children.
\end{abstract}

Keywords:

Performance, Social Workers, Children Require Special Protection 


\section{INTRODUCTION}

NASW in Adi Fahrudin (2012) states that social work is a professional activity that helping individual, group or community to improve or restore their ability to function socially and to create social conditions that support these goals. The practice of social work consists of the professional application of the values, principles and techniques of social work to one or more of the following objectives: helping people obtain tangible services; provide counseling and psychotherapy for individual, family and group; help community or group to provide or improve social and health services; and to participate in related legislative processes. The practice of social work requires knowledge about human development and behavior; social, economic and cultural institutions; and about the interaction among all of these factors.

In Permensos No. 8/2012 it is explained that a professional social worker is someone who works, both in government and private institutions who has the competence and profession of social work, and care in social work which obtained through education, training, and/or experience of social work practices for carrying out service tasks and handling social problems.

One kind of People with Social Welfare Problems (PMKS) in micro practices is a children problem. In Permensos No. 8 of 2012 concerning Guidelines for Data Collection and organization of Data on People with Social Welfare Problems and the Potential and Sources of Social Welfare, there are two types of children that need attention and treatment, namely neglected children and children who need special protection.

Neglected children are children aged
6 (six) years up to 18 (eighteen) years including children who have been mistreated and abandoned by parents/family or children who lost custody of parents/family. Children who need special protection are children aged 6 (six) to 18 (eighteen) years in an emergency situation, from minority groups and isolated, economically and/or sexually exploited, trafficked, the victims of narcotics, alcohol abuse, psychotropic substances, and other addictive substances, victims of abductions, trafficking, victims of physical and/or mental violence, who have disabilities, and victims of mistreatment and neglect.

The Problems with children have become the nation's commitment, in other words, children's problems regarding independence and meeting the needs of children are the responsibility of the government, society, family and especially protection from parents. The state and related parties must work harder to save abandoned children or face other problems. Because, it turns out the number of children affected by parenting problems is very large, reaching 4.1 million people. This fact was conveyed by former Social Minister Khofifah based on Data Center and Information (Pusdatin) Social Ministry in 2015. In addition, in 2018, the Directorate General of Social Rehabilitation identified 16,290 street children throughout Indonesia. The highest number of street children in West Java Province was 2,953 children.

Related to this data, it shows that the children's problems are continuously overcome, especially related to the fulfillment of their rights. This is because in reality there are still many children who are neglected intentionally or unintentionally by parents, family and community. Many children living 
without parents, so to encourage the country to make efforts to protect abandoned children through social institutions specifically for children.

Child Social Rehabilitation Institutions

Requires Special Protection (PSRAMPK) Pagaden Subang is one of the Technical Implementation Unit (UPTD) under the auspices of the West Java Provincial Social Office. PSRAMPK is one of the institutions that protect children's rights as a substitute for the family to provide social services both physically and mentally. Based on the 2018 PSRAMPK profile, the services provided to children include child care, formal education, skills development, spiritual coaching, social coaching, sports and arts activities. Overall this service is generally intended to help improving the welfare of children with target to educate foster children to be independent and be able to develop and grow well so that they can carry out social functions as member of the community.

PSRAMPK has the duty to save and protect children under five, neglected children and children who experience social dysfunction, so that they can naturally grow to become productive human resources through several things. First, meeting the basic needs of neglected children includes food, clothing, shelter, health, education, protection, equality of treatment, and mental and spiritual needs. Second, the creation of social functioning of neglected children and children who experience social dysfunction so that they can re-display their roles. Third, overcoming the difficulties experienced by children as a result of neglect experienced. Fourth, the creation of environmental and life situations that support social functioning and prevent the recurrence of neglect. Fifth, by increasing the reach of children's social welfare services, both in the orphanage/sub-unit of the shelter house as well as outside the ordinate of the orphanage/sub-unit of the shelter house.

In carrying out social services, PSRAMPK is inseparable from the important role of social workers who are the main profession in PSRAMPK Pagaden Subang. In PSRAMPK Pagaden Subang itself, there are seven social workers consisting of two ASN social workers and five Non ASN social workers whose main task is to provide assistance to foster children who are in PSRAMPK. However, the number of social workers is not yet balanced with the number of foster children they must assist. In PSRAMPK the total of 100 (hundred) foster children must be accompanied by seven social workers. This certainly becomes a challenge for social workers to maintain their performance so that they remain good in carrying out their main tasks, functions and roles.

Kasmir (2015) states that performance has a close relationship with productivity problems because it is an indicator in determining how the effort to achieve high levels of productivity in an organization. In connection with this, the effort to conduct an assessment of the performance in an organization is important. Performance standards need to be formulated in order to be used as benchmark in making comparisons between what has been done with what is expected, in relation to the work or position that has been entrusted to someone. The standard in question or intended is also used as a measure in holding responsibility for what has been done. This is because in practice, it is not always that the performance of social workers in conditions as desired either by the 
social worker itself or the organization. Many obstacles affect the performance of both organizational performance and individual performance.

The level of service received by foster children in PSRAMPK will certainly depend on the performance of social workers in providing services which will certainly affect the success of social workers in the orphanage. In addition to social workers, the success of this service will also affect the existence of institutions in the community.

This eventually became the motivation of the writer to examine the performance of social workers. Apart from the curious factor, the greatest motivation of the writer is want to explore the practice of social workers, especially when in an orphanage.

\section{Problem Formulation}

The formulation of the problem of this research is: "How Does the Performance of Social Workers at Children's Social Rehabilitation Institution Requires Special Protection in Pagaden Subang?". Furthermore, this research is focused on:

a. What are the characteristics of the informants?

b. How is about the work performance of social workers?

c. How is about the discipline of social workers?

d. How is about the creativity of social workers?

e. What about social worker cooperation?

f. What are the responsibilities of social workers?

\section{Research Purposes}

The purpose of this research is to examine systematically, factually and accurately about: a. Characteristics of the informants

b. Work performance of social workers

c. Discipline of social workers

d. Creativity of social workers

e. Social worker cooperation

f. The responsibilities of social workers

\section{METHOD}

The research method used to examine the performance of social workers at the Child Social Rehabiliation Institutions Requires Special Protection (PSRAMPK) Pagaden Subang is a descriptive method with a qualitative approach

According to Nazir (2014: 43):

"Descriptive method is a method in examining the status of a group of people, an object, a set of conditions, a system of thought, or a class of events in the present. The purpose of the descriptive research is to make a description, illustration or picture systematically, factual and accurate concerning the facts, characteristics or attributes and relationships among the phenomena that are under investigated"

According to Moleong (2016: 6):

"Qualitative research is research intended to understand phenomena about what is experienced by research subjects such as behavior, perception, motivation, action, etc.; holistically, and by means of descriptions in the form of words and language, in a particular natural context and by utilizing various natural methods"

Qualitative research yielded and processes of data in a descriptive manner such as interview transcripts, field notes, and documentation of activities. Using interview techniques, participatory observation, and study documentation in order to make 
understand the phenomenon under study.

Data sources used in this research are primary data sources and secondary data sources:

\section{Primary data source}

Primary data sources are data sources obtained directly from research subjects, in this matter that is structural officials, social workers, caregivers and foster children in PSRAMPK Pagaden Subang)

\section{Secondary data source}

Secondary data sources used in this research are data sources obtained indirectly from research subjects such as photographic evidence of the subject's activities, video recorders and research documentation from supporting subjects in research about the performance of social workers.

\section{Data collection technique}

Data collection is an important activity in research. Data collection techniques used in this research are in-depth interview, documentation study and participative observation.

\section{4, In-depth interview}

In-depth interview are data retrieval techniques carried out with question and answer while face to face between researcher and subjects. In-depth interview was conducted by researcher to obtain in- depth information about the performance of social workers at PSRAMPK Pagaden Subang. In - depth interview was conducted for each subject (Structural PSRAMPK Pagaden Subang) based on interview guidelines that had been prepared.

\section{Documentation Study}

This data collection technique was carried out to obtain an overview of research location and service programs that exist in the institution, as well as data about the performance of social workers and other data relating to research conducted at the PSRAMPK Pagaden Subang.

Documentation study was also carried out through recordings and photographs of subjects. The documentation study is a complement from interview method and participative observation. So that the information obtained by researchers is complete and has documentation.

\section{Participative observation}

Researchers used participative observation techniques, where researcher was directly involved in the activities of the PSRAMPK Pagaden Subang. Participative observation was conducted in order to make understand the behavior and activities including the informants' words, feelings and actions directly

\section{RESEARCH RESULT}

\section{Job Performance}

A summary about work performance can be seen in Table 1.1 as follows

Table 1.1 Summary of of Job Performance

\begin{tabular}{|c|l|l|}
\hline No & \multicolumn{1}{|c|}{ Theme } & \multicolumn{1}{c|}{ Finding } \\
\hline 1 & \multicolumn{1}{|c|}{2} & \multicolumn{1}{c|}{3} \\
\hline 1. & $\begin{array}{l}\text { The skills of } \\
\text { social workers } \\
\text { in carrying out } \\
\text { tasks }\end{array}$ & $\begin{array}{l}\text { Social workers are not yet capable in carrying out their duties. Social workers } \\
\text { have not been able to carry out further assessments and assistance due to the } \\
\text { imbalance in the number of social workers with foster children to be } \\
\text { handled. In addition, all new social workers must adapt to the environment }\end{array}$ \\
\hline
\end{tabular}




\begin{tabular}{|l|l|l|}
\hline & & around the orphanage \\
\hline 2 & $\begin{array}{l}\text { Seriousness of } \\
\text { social workers in } \\
\text { carrying out the } \\
\text { task }\end{array}$ & $\begin{array}{l}\text { Social workers need to increase the seriousness in carrying out their duties, } \\
\text {,how The seriousness of social workers have been seen from thereports they } \\
\text { do ever, social workers are not so close to children and have not made a } \\
\text { schedule for counseling of children. }\end{array}$ \\
\hline 3 & $\begin{array}{l}\text { The suitability of } \\
\text { the } \\
\text { implementation of } \\
\text { activities with the } \\
\text { activity schedule }\end{array}$ & $\begin{array}{l}\text { Social workers carry out activities according to the scheduled time. The } \\
\text { schedule that was previously prepared is a reference for social workers in } \\
\text { carrying out their duties. In addition, the stay of social workers in the } \\
\text { institution or orphanage also helps facilitate social workers in ensuring } \\
\text { every activity. }\end{array}$ \\
\hline
\end{tabular}

Based on Table 1.1, it can be seen that social workers have not been able to maximize various efforts so that they are still less capable in carrying out their tasks. Social workers are hampered by the total of social workers who are still not balanced when compared with the total of foster children. Besides that, social workers also have not been able to develop maximum closeness with children due to their working time is relatively short time. Social workers also have not made various efforts to carry out their duties seriously. Social workers need to increase the seriousness in carrying out their duties. The seriousness of social workers has been seen from the reports they do, however, social

\section{Discipline}
A summary about the discipline can be seen
in
Table

workers have not been so close to children and have not made a counseling schedule.

The skills and seriousness of social workers are still lacking, however, the appropriateness of implementation with the scheduled time in carrying out social workers' tasks is good enough. Based on table 1.1, it can be seen that social workers make a schedule of activities as a reference in carrying out the task. In addition, social workers also make the schedule of activities as a tool to facilitate reporting that will be submitted to supervisors. Then, the stay of social workers in the institution or orphanage also makes it easier for them to carry out their tasks so that the activities are carried out on time

Table 2.1 Summary of Discipline

\begin{tabular}{|c|c|l|}
\hline No & Theme & \multicolumn{1}{|c|}{ Finding } \\
\hline 1 & 2 & $\begin{array}{l}\text { Social workers learn the rules and policies relating to the tasks of social } \\
\text { workers so that they understand their duties and obligations. In addition, } \\
\text { social workers always inform the activities that they carry out to } \\
\text { supervisors so that they get guidance and direction. }\end{array}$ \\
\hline 2. & $\begin{array}{c}\text { Arrive on time for } \\
\text { each activity }\end{array}$ & $\begin{array}{l}\text { Social workers arrive early in any activity that they participate in, either } \\
\text { activities with foster children or organized activities that are assigned by } \\
\text { the orphanage to participate in. Social workers also live in the orphanage, } \\
\text { making it easier for them to ensure that they are on time for activities in } \\
\text { the orphanage. }\end{array}$ \\
\hline 3. & $\begin{array}{c}\text { Work on and } \\
\text { complete tasks in }\end{array}$ & $\begin{array}{l}\text { Social workers make a schedule of activities along with the deadline for } \\
\text { implementation and reporting on activities that have been carried out, } \\
\text { social workers also report the progress of tasks to supervisors, and there is }\end{array}$ \\
\hline
\end{tabular}




\begin{tabular}{|l|l|l|l|}
\hline $\begin{array}{l}\text { complete tasks in } \\
\text { accordance with the } \\
\text { scheduled } \\
\text { time }\end{array}$ & $\begin{array}{l}\text { assistance from supervisors and operators in reminding mandated } \\
\text { tasks to social workers }\end{array}$ \\
\hline
\end{tabular}

Based on Table 2.1 it can be understood that social workers are disciplined in carrying out their duties. Social workers do various ways to be disciplined in every activity for example learning the rules or policies relating to the tasks of social workers. These efforts are carried out by social workers so that the tasks and activities they carry out are in accordance with regulations. Social workers also try to be disciplined in time. Social workers arrive early in every activity they participate to be present on time and not late.

\section{Creativity}

A summary about the creativity of social workers in carrying out their tasks can be seen in Table 3.1 below:
Social workers also try to be disciplined in completing tasks according to the scheduled time. The social worker assigns a time limit on the schedule of activities so as to make time efficient in mapping tasks. Another thing that social workers do is to report any activities to supervisors to make it easier for them to remember and prepare the needs toward the activities that will be carried out later.

Table 3.1 Summary of Creativity

\begin{tabular}{|c|c|c|}
\hline No & Theme & Finding \\
\hline 1 & 2 & 3 \\
\hline 1. & $\begin{array}{l}\text { Solve problems } \\
\text { in a short time }\end{array}$ & $\begin{array}{l}\text { Social workers are still able to deal with the problems they face by dividing } \\
\text { the task of handling children's problems so that all children's problems can be } \\
\text { resolved. Social workers will cooperate with each other if there are obstacles } \\
\text { in solving the problems encountered so that the problem can be resolved } \\
\text { immediately. In addition, social workers were given direction and input from } \\
\text { the Head of the Social Welfare Services Section related to handling child } \\
\text { problems. } \\
\text { Social workers also often involve caregivers and other employees in handling } \\
\text { problems that need quick handling. }\end{array}$ \\
\hline 2. & $\begin{array}{l}\text { The ability to } \\
\text { handle } \\
\text { unpredictable } \\
\text { conditions and } \\
\text { are required to } \\
\text { change activity } \\
\text { plans }\end{array}$ & $\begin{array}{l}\text { Social workers have not faced unpredictable conditions so that can be } \\
\text { overcome by social workers. The problems faced by social workers are not } \\
\text { too complicated. If faced with situations that require changing the plan of } \\
\text { activities, the social worker will see the priority scale of activities and which } \\
\text { activities can be postponed. }\end{array}$ \\
\hline 3. & $\begin{array}{l}\text { Creating } \\
\text { something new }\end{array}$ & $\begin{array}{l}\text { Social workers who currently newcomer work at PSRAMPK have advantages } \\
\text { in terms of age and education. These social workers have broad insights and } \\
\text { high morale so they are encouraged to create activities that can of social } \\
\text { workers innovation become s a distraction so that children are not } \\
\text { easily bored. The activity was also carried out so that the approach of social } \\
\text { workers }\end{array}$ \\
\hline
\end{tabular}




\begin{tabular}{|l|l|l|}
\hline & & Workers towards children would be better in the future \\
\hline 4. & $\begin{array}{l}\text { The efforts made by social workers so that details in carrying out the task } \\
\text { are seen when the social worker conducts the initial assessment by making } \\
\text { a priority scale of prospective foster children complete with photo } \\
\text { documentation that supports the truth of the information when the initial } \\
\text { assessment is carried out. } \\
\text { duties in detail their } \\
\text { Detailed information provided by social workers is considered to facilitate } \\
\text { structural officials in determining appropriate foster children to be } \\
\text { provided with services. Social workers are always honest in doing their } \\
\text { work by writing all the activities they carry out in routine reports every } \\
\text { month. Supported by documentary evidence and absence activities, in } \\
\text { addition to adding to the completeness of the report also makes the report } \\
\text { valid and can be justified. }\end{array}$ \\
\hline
\end{tabular}

Based on Table 3.1 it can be understood that social workers are able to deal with problems that occur by cooperating with each other. The problems faced by social workers do not yet require special intervention or change the activity plan. If there is an event that requires changing the activity plan then the social workers will look at the priority scale of the activity.

Social workers also carry out their duties in detail. Routine reports that are given

\section{Cooperation}

A summary about the aspects of cooperation can be seen in Table 4.1 as follows:

Table 4.1 Cooperation monthly to the Head of the Social Welfare Services Section have made correctly monthly and in detail by the social workers. Social workers also have made innovations in carrying out tasks. Young social workers have broad insights and high morale so that they are encouraged to create activities that can increase the potential and creativity of children while at orphanage. Social worker innovation becomes a distraction so that children are not easily bored.

\begin{tabular}{|c|l|l|}
\hline No & \multicolumn{1}{|c|}{ Theme } & \multicolumn{1}{c|}{ Finding } \\
\hline 1 & \multicolumn{1}{|c|}{2} & \multicolumn{1}{c|}{3} \\
\hline 1. & $\begin{array}{l}\text { Cooperation and } \\
\text { coordination with } \\
\text { related parties }\end{array}$ & $\begin{array}{l}\text { Cooperation and coordination with a team of structural officials, social } \\
\text { worker's colleagues, orphanage/nursing staff, caregivers and foster } \\
\text { children are well established. Social workers make various efforts to get } \\
\text { closer to foster children so that cooperation and coordination become } \\
\text { better. }\end{array}$ \\
\hline 2. & $\begin{array}{l}\text { Mutual respect } \\
\text { between } \\
\text { coworkers }\end{array}$ & $\begin{array}{l}\text { Mutual respect between colleagues arises from frequent cooperation and } \\
\text { they already know each other. }\end{array}$ \\
\hline 3 & $\begin{array}{l}\text { Mutual respect } \\
\text { with foster } \\
\text { children }\end{array}$ & $\begin{array}{l}\text { Social workers already know foster children that are their responsibility so } \\
\text { that it is easy for them to respect and understand each other. }\end{array}$ \\
\hline
\end{tabular}

Based on Table 4.1, it can be understood that the cooperation and coordination developed by social workers with related parties are well established so that they are cooperative in carrying out their duties. Cooperation and coordination of social workers with foster 
children is quite good. Social workers also already know the character of foster children in general so that it is easy for social workers to put position themselves when with foster

\section{Responsibility}

A summary about the aspects of responsibility can be seen in table 5.1 as follows: children. Furthermore, fellow social workers have known each other. Therefore, fellow social workers understand and respect each other.

Table 5.1 Summary of Responsibilities

\begin{tabular}{|c|c|l|}
\hline No & Theme & \multicolumn{1}{|c|}{ Finding } \\
\hline 1 & 2 & \multicolumn{1}{c|}{3} \\
\hline 1. & $\begin{array}{c}\text { Quite good in } \\
\text { carry out } \\
\text { individual tasks. }\end{array}$ & $\begin{array}{l}\text { Social workers are quite good in carrying out individual tasks. This is } \\
\text { evidenced by the preparations made by social workers to prepare the } \\
\text { necessity needed. }\end{array}$ \\
\hline 2. & $\begin{array}{c}\text { Maintaining } \\
\text { good relations } \\
\text { with their } \\
\text { environment }\end{array}$ & $\begin{array}{l}\text { Social workers have made a way to be close to their environment through } \\
\text { greetings smiling. Then, social worker maintains the relationship by being } \\
\text { friendly and respecting each other's opinions. }\end{array}$ \\
\hline 3. & $\begin{array}{c}\text { Daring to take } \\
\text { decisions in } \\
\text { carrying out } \\
\text { their duties }\end{array}$ & $\begin{array}{l}\text { Various parties. So that social workers dare to take these decisions and take } \\
\text { responsibility }\end{array}$ \\
\hline
\end{tabular}

Based on Table 5.1 we can understand that social workers carry out individual tasks quite well. Social workers prepare the tools needed to carry out activities. Social workers also maintain good relations with the surrounding

\section{DISCUSSION}

Performance is the result of a person work in achieving the goals he or she has made before. Performance consists of aspects of work performance, discipline, creativity, cooperation, and responsibility. Research about the performance of social workers was conducted on 8 (eight) informants consisting of social workers, structural officials, caregivers and foster children. Informants are expected to understand that social workers duties to carry out social welfare services in each institution according to Kepmenpan No. 3 of 2004 concerning the Position of Social Workers and Their Credit Scores as well as environment and dare to make decisions. Decisions made by social workers can be justified because they have been consulted and coordinated with various partie.

Kepmensos No. 10/Huk/2007 concerning Guidelines for Technical Guidance on Functional Position of Workers. The policy confirms that social workers have a very important role in the success of the orphanage service program so that the goals of the Child Social Rehabilitation Institutions Requires Special Protection Pagaden Subang can be achieved.

The performance of social workers in daily life can be interpreted as a result of carrying out the tasks performed by social workers. According to Kasmir (2015:182) performance is the result of work and work 
behavior of a person in a period, usually one year. Therefore, a person's performance will affect the organization that supports it. In addition, a person's performance also determines the achievement of the goals of the organization. The following discussion regarding the results of research that are translated into each aspect of performance.

\section{Job Performance}

The results of research about aspects of work performance which done show that social workers in the PSRAMPK have not been able to maximize various efforts so that they are still less capable in carrying out tasks. Social workers are hampered by the total of social workers who are still not balanced when compared with the total of foster children. In addition, social workers also have not been able to develop closeness with children in a maximum manner due to their working time is relatively short time.

Social workers also have not made various efforts to carry out their duties seriously. Social workers need to increase the seriousness in carrying out their duties. The seriousness of social workers has been seen from the reports they do, however, social workers have not been so close to children and have not made a counseling schedule.

The skills and seriousness of social workers are still lacking, however, the appropriateness of implementation with the scheduled time in carrying out social workers' tasks is good enough. Social workers make a schedule of activities as a reference in carrying out the task. In addition, social workers also make the schedule of activities as a tool to facilitate reporting that will be submitted to supervisors. Then, the stay of social workers in the institution or orphanage also makes it easier for them to carry out their tasks so that the activities are carried out on time.

According to Lawyer \& Porter in As'ad (1991) states that work performance is the success of work obtained by someone from the actions or results concerned. Whereas Jewell and Siegal in Umam (2012) stated that work performance is the result of the extent to which members of the organization have done work in order to satisfy their organization.

Based on the explanation above, that work performance is success in doing work to achieve maximum results. The success of the work is the determination and completeness in carrying out the duties and work, meaning that there is a match between the planned activities with the goals or objectives that have been determined. There is also a link between work performance and work success.

In connection with it can be ensured that social workers have not been successful in doing their jobs because the results achieved have not been maximized. In some tasks stages, the social worker service have not been able to complete it according to the target. This is due to the limited number of social workers in the institution, the lack of seriousness of social workers in carrying out their duties, and the lack of experience of young social workers in adjusting to the work rhythm in the PSRAMPK.

\section{Discipline}

The results of research about the performance of social workers in the disciplinary aspect shows that social workers are disciplined in carrying out 
tasks. Social workers do various ways to be disciplined in every activity for example learning the rules or policies relating to the tasks of social workers. These efforts are carried out by social workers so that the tasks and activities they carry out are in accordance with regulations. Social workers also try to be disciplined in time. Social workers arrive early in every activity they participate to be present on time and not late.

Social workers also try to be disciplined in completing tasks according to the scheduled time. The social worker assigns a time limit on the schedule of activities so as to make time efficient in mapping tasks. Another thing that social workers do is report any activities to supervisor to make it easier for them to remember and prepare the needs toward the activities that will be carried out later.

In essence, worker discipline is a willingness to comply with all the rules and norms that exist in carrying out their duties as a form of responsibility for their work. Obeying the rules of the job is proof that someone is loyal to his job. Besides that, this also becomes part of the safety work.

Social workers in carrying out their duties already meet the criteria of an employee discipline due to his adherence to the rules and norms that exist in carrying out the tasks he is carrying. This can be seen from the efforts of social workers to arrive on time in every activity, do not rule out the rules of the orphanage in the process of service to children and try to enforce these rules to the surrounding environment. Discipline of social workers is a form of obligation and responsibilities as workers also become part of safeguarding social worker malpractice in the delivery of services.

\section{Creativity}

The results show that social workers are able to deal with problems that occur by cooperating with each other. The problems faced by social workers do not yet require special intervention or change the activity plan. If there is an event that requires changing the activity plan then the social worker will look at the priority scale of the activity.

Social workers also carry out their duties in detail. Routine reports that are given monthly to the Head of the Social Welfare Services Section have made correctly and in detail by the social workers. Social workers also have made innovations in carrying out tasks. Young social workers have broad insights and high morale so that they are encouraged to create activities that can increase the potential and creativity of children while at orphanage. Social worker innovation becomes a distraction so that children are not easily bored.

Creativity itself is a person's ability to see with new perspectives and the ability to find new relationships. A new perspective is the point of view to determine a new idea. The ability to find new relationships is intended to see the extent to which workers or employees interact.

Social workers in this case have been fulfilled an aspect of a worker's creativity because of their efforts in developing service capabilities with the latest scientific perspective. This is proven in the research that young social workers who are fresh graduates are able to create new activities in the service process so that they can become a distraction for children's 
activities. Efforts made by social workers are carried out solely to improve the quality of services to children. Social workers also have the ability to work together in overcoming a problem in the service so that the problems encountered can be resolved immediately.

\section{Cooperation}

The results of research about aspects of cooperation undertaken by social workers with various parties show that social workers always cooperate and coordinate with parties - that the cooperation and coordination developed by social workers with related parties are well established so that they are cooperative in carrying out their duties. Cooperation and coordination of social workers with foster children is quite good. Social workers also already know the character of foster children in general so that it is easy for social workers to put their position themselves when with foster children. Furthermore, fellow social workers have known each other. Therefore, fellow social workers understand and respect each other.

Cooperation is needed to complete the work effectively and efficiently. Cooperation is a joint activity between two or more to achieve the same goal, in this case to resolve the client problems. Cooperation that intended is a cooperation between social workers and all related parties both institutionally or interpersonally.

The social worker at PSRAMPK is considered to meet the cooperation criteria in the aspect of a worker's performance. In the research results, social workers have tried to carry out activities together with other social workers and other orphanage employees to complete work effectively and efficiently. This can be seen from the efforts of social workers to build cooperation with structural officials, social worker colleagues, orphanage or nursing staff, caregivers and foster children as a single unity in the service process at PSRAMPK.

\section{5. Responsibility}

The research results showed that social workers are already responsible for carrying out their duties. This is because social workers have carried out individual tasks quite well. The attitude of responsibility of social workers can be seen from how to prepare the tools needed in the implementation of activities, maintain good relations with the surrounding environment and dare to make decisions. Decisions made by social workers can also be justified because they have been consulted and coordinated with various parties.

Someone who is responsible to be consciously knows of his job so he will give all his ability to do work. Responsibility is the willingness of employees to account for their work results, the things that they used, and work behavior. When someone is willing to be held accountable means he is sure that he has done his job on the track.

Social workers consciously know their duties and obligations so that social workers also try to provide their abilities in doing work. This is based on the results of the research shows that social workers maximize preparation in carrying out an activity and consider many things in making a decision so that whatever is done by social workers can be accounted for. 


\section{CONCLUSION}

Research about the performance of social workers at the Children's Social Rehabilitation Institutions Requires Special Protection Pagaden Subang was carried out toward social workers, superiors or supervisors of social workers consisting of the Head of the Social Welfare Services Section and the Head of Reception and Distribution Section, as well as caregivers and foster children with total of eight people. Informants in this research consisted of 2 (two) structural officials, 2 (two) social workers, 2 (two) caregivers, and 2 (two) foster children. The Head of the Social Welfare Services Section and the Head of the Reception and Distribution Section have been hold this position since 2018, while social workers started working at PSRAMPK since 2017 and 2018. The length of time working for caregivers also varies, some have been caregivers for 16 (sixteen) years but there are also those that work for around 4 (four) years.

Based on the research results conducted at the Children's Social Rehabilitation Institutions Requires Special Protection Pagaden Subang with 8 (eight) informants, it can be said that social workers have worked and carried out their duties properly. Social workers show good performance such as discipline in doing their jobs and obeying the rules. In addition, social workers are also responsible for every their actions and always cooperation and coordinate with relevant parties. Although, in carrying out their duties there are several things that have not been maximized. Performance in this case is seen from the aspects of work performance, discipline, responsibility, creativity, and cooperation.

Job performance shows that social workers have not been able to carry out various tasks. Social workers have not been able to maximize various efforts so that they are still less capable in carrying out tasks. This is because the total of social workers is not proportional to the total of foster children who must be accompanied and provided services. Besides that, social workers also have not been able to build maximum closeness with children due to their working time is relatively short time. Social workers also have not made various efforts to seriously carry out their duties. Social workers need to increase the seriousness in carrying out their duties. The seriousness of social workers has been seen from the reports they do, however, social workers have not been so close to children and have not made a counseling schedule.

Discipline shows that social workers are disciplined in carrying out their duties. Social workers do various ways to be disciplined in every activity for example learning the rules or policies relating to the tasks of social workers. These efforts are carried out by social workers so that the tasks and activities they carry out are in accordance with regulations. Social workers also try to be disciplined in time. Social workers arrive early in every activity they participate to be present on time and not late.

Creativity shows that social workers are able to deal with problems that occur by cooperating with each other. The problems faced by social workers do not yet require special intervention or change the activity plan. If there is an event that requires changing the activity plan then the social worker will look at the priority scale of the activity.

Social workers also carry out their duties in detail. Routine reports that are given monthly to the Head of the Social Welfare 
Services Section have made correctly and in detail by the social workers. Social workers also have made innovations in carrying out tasks. Young social workers have broad insights and high morale so that they are encouraged to create activities that can increase the potential and creativity of children while at orphanage. Social worker innovation becomes a distraction so that children are not easily bored.

Cooperation shows that the cooperation and coordination developed by social workers with related parties are well established so that they are cooperative in carrying out their duties. Cooperation and coordination of social workers with foster children is quite good. Social workers also already know the character of foster children in general so that it is easy for social workers to position themselves when with foster children. Furthermore, fellow social workers have known each other. Therefore, fellow social workers understand and respect each other.

Responsibility shows that social workers carry out individual tasks quite well. Social workers prepare the tools needed to carry out activities. Social workers also maintain good relations with the surrounding environment and dare to make decisions. Decisions made by social workers can be justified because they have been consulted and coordinated with various parties. Based on the research results it can be understood that aspects of performance towards social workers are quite good but in some cases it needs to be improved and developed. Referring to the research results, the researchers concluded that there was a need to develop a program to improve the performance of social workers through Capacity Building through Social
Worker Technical Guidance in Providing Services to Children.

Further research needs to be done in order to complete and perfect the results of this research with different variables, aspects, and research locations, namely:

1. Further research is expected to illustrate more clearly the ability, seriousness and skills of social workers in providing services to children.

2. Research can be carried out in different locations in order to describe the performance of social workers in providing services to other types of people with social welfare problems.

3. Further research can focus on the relevancy between the performance of social workers and the existence of institutions that support them.

4. Further research about the performance of social workers can be done with different aspects of research. Research with different aspects can be done in the same location or in a different location.

5. Further research can be done by focusing on just one task of social workers

This further research is expected to be able to develop research about the performance of social workers in a better direction so as to supplement the shortcoming in previous research.

\section{REFERENCES}

Amalia, Fahrunissa Ayu. 2015. Kinerja Pengurus Panti dalam Pemberian Pelayanan di Panti Werdha Sultan Fatah Kabupaten Demak Provinsi Jawa Tengah. Bandung: STKS

As'ad. 1991. Seri Ilmu Manajemen Sumber Daya Manusia Psikologi Industri. Bandung: Alumni

Fahrudin, Adi 2012. Pengantar 
Kesejahteraan Sosial. Bandung: PT. Refika Aditama.

Hasibuan, Malayu. 2003. Manajemen Sumber Daya Manusia. Cetakan keenam. Jakarta: PT Bumi Aksara

Hasmi, Muhammad Nur Ali 2015. Kinerja Pengurus Lembaga Advokasi Hak Anak (LAHA) dalam Penanganan Anak Berkonflik dengan Hukum (ABH) di Lembaga Pembinaan Khusus Anak (LPKA). Bandung: STKS

Huraerah, Abu. 2007. Child Abuse (Kekerasan Terhadap Anak). Bandung: Nuansa

Kasmir. 2016. Manajemen Sumber Daya Manusia. Edisi kedua. Cetakan pertama. Jakarta: Rajawali Pers

Moleong. 2016. Metodologi Penelitian Kualitatif. Bandung: PT Remaja Rosadakarya

Muhamardani. 2015. Kinerja Satuan Bakti pekerja Soial (Sakti Pekerja Sosial) dalam Penanganan Penyandang Masalah Kesejahteraan Sosial di Kota Pangkalpinang. Bandung: STKS

Nazir. 2014. Metode Penelitian. Bogor: Ghalia Indonesia.

Peraturan Menteri Sosial RI Nomor 08 Tahun 2012 tentang Pedoman Pendataan dan Pengelolaan data Penyandang Masalah Kesejahteraan Sosial dan Potensi dan Sumber Kesejahteraan Sosial.

Saleh, Choirul, dkk. 2013. Pengembangan Kompetensi Sumber Daya Aparatur. Malang: UB Press

Sinta Hartono. 2015. Kinerja Pekerja Sosial

Dalam Pelayanan Dan Rehabilitasi Sosial Korban Napza di Balai Rehabilitasi Sosial Pamardi Puta Lembang Bandung. Bandung: STKS

Soemantri, S. 2006. Psikologi Anak Luar Biasa. Bandung : Refika Aditama

Sugiyono. 2010. Metode Penelitian Kuantitatif Kualitatif dan R\&D. Bandung: Alfabeta.

Sukoco, Dwi Heru. 2011. Profesi Pekerjaan Sosial dan Proses Pertolongannya. Bandung: Kopma Sekolah Tinggi Kesejahteraan Sosial (STKS) Bandung
Taupik, Mohammad Pajar. 2014. Kinerja Pendamping Program Keluarga Harapan di Kecamatan Nagreg Kabupaten Bandung. Bandung: STKS

Umam, Khoirul. 2012. Perilaku Organisasi. Bandung: Pustaka Setia 
